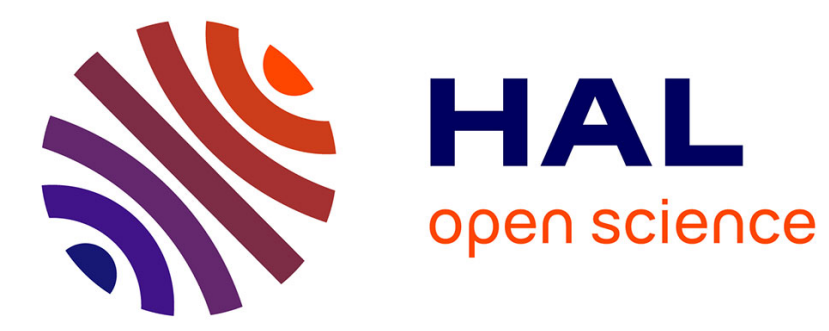

\title{
Additional retardation in RAFT polymerization: Detection of terminated intermediate radicals
}

Mael Bathfield, Franck d'Agosto, Roger Spitz, Catherine Ladaviere, Marie-Therese Charreyre, Thierry Delair

\section{- To cite this version:}

Mael Bathfield, Franck d'Agosto, Roger Spitz, Catherine Ladaviere, Marie-Therese Charreyre, et al. Additional retardation in RAFT polymerization: Detection of terminated intermediate radicals. Macromolecular Rapid Communications, 2007, 28 (7), pp.856-862. 10.1002/marc.200600861 . hal01877425

\section{HAL Id: hal-01877425 \\ https://hal.science/hal-01877425}

Submitted on 18 Nov 2020

HAL is a multi-disciplinary open access archive for the deposit and dissemination of scientific research documents, whether they are published or not. The documents may come from teaching and research institutions in France or abroad, or from public or private research centers.
L'archive ouverte pluridisciplinaire HAL, est destinée au dépôt et à la diffusion de documents scientifiques de niveau recherche, publiés ou non, émanant des établissements d'enseignement et de recherche français ou étrangers, des laboratoires publics ou privés. 


\title{
Additional Retardation in RAFT Polymerization:
}

\section{Detection of Terminated Intermediate Radicals}

\author{
Maël Bathfield, ${ }^{1,2}$ Franck D'Agosto, ${ }^{* 1}$ Roger Spitz, ${ }^{1}$ Catherine Ladavière, ${ }^{2}$ Marie-Thérèse \\ Charreyre, ${ }^{* 2}$ Thierry Delair ${ }^{2}$
}

This is a post-peer-review, pre-copyedit version

(i.e. the current layout was made by the authors) of an article published in Macromolecular Rapid Communications.

The final authenticated version is available online at:

https://doi.org/10.1002/marc.200600861

\section{Graphical TOC}

An over-retardation epiphenomenon has been observed during RAFT polymerization of $\mathrm{N}$ acryloylmorpholine mediated by several bio-functional dithioesters. This epiphenomenon has been related to termination reactions onto intermediate radicals. The resulting three-arm species have been observed for the first time in RAFT polymerization conditions by MALDITOF mass spectrometry.

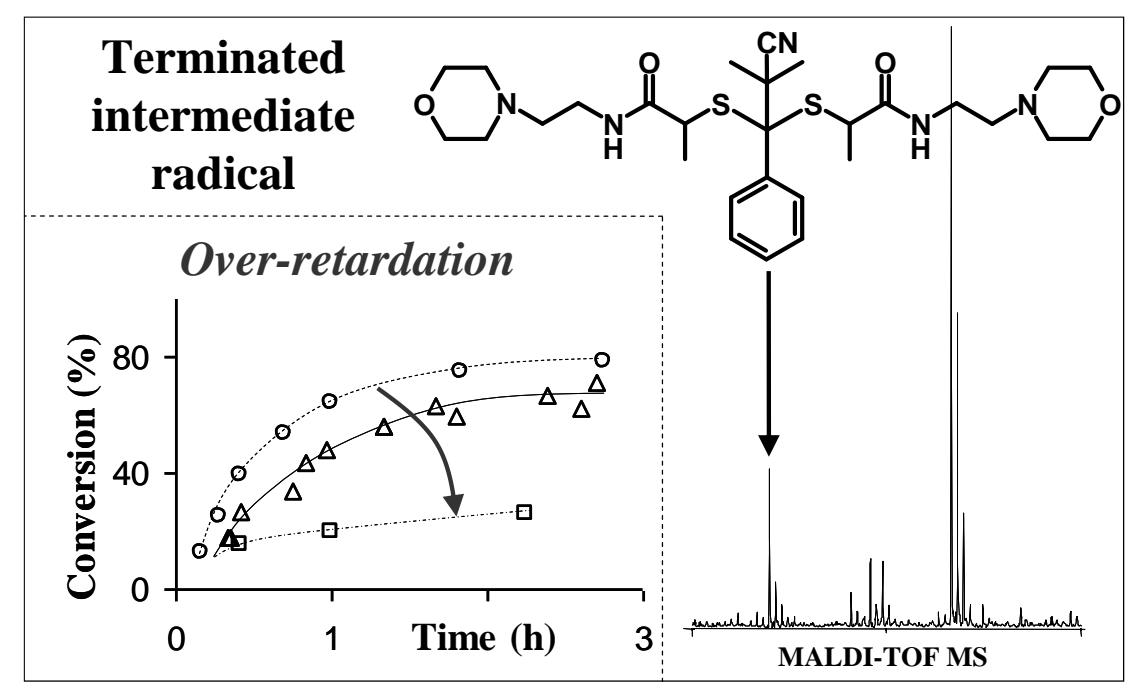




\section{Additional Retardation in RAFT Polymerization:}

\section{Detection of Terminated Intermediate Radicals}

Maël Bathfield, ${ }^{1,2}$ Franck D'Agosto, ${ }^{* 1}$ Roger Spitz, ${ }^{1}$ Catherine Ladavière, ${ }^{2}$ Marie-Thérèse Charreyre, ${ }^{* 2}$ Thierry Delair ${ }^{2}$

1. Laboratoire de Chimie et Procédés de Polymérisation UMR 140 CNRS/ESCPE, Bât 308 F, 43 Boulevard du 11 Novembre 1918, BP 2077, 69616 Villeurbanne CEDEX, France $\underline{\text { WwW.lcpp-cpe.com }}$

2. Unité Mixte CNRS/bioMérieux, École Normale Supérieure de Lyon, 46 allée d'Italie, 69364 Lyon Cedex 07, France

Corresponding Authors: F. D’Agosto (dagosto@lcpp.cpe.fr), M.-T. Charreyre (mtcharre@ens-lyon.fr) 


\section{Keywords}

Reversible Addition Fragmentation chain Transfer (RAFT), kinetics (polym.), terminated intermediate radicals, Matrix-Assisted Laser Desorption/Ionization Time of Flight Mass Spectrometry (MALDI ToF MS).

\section{Summary}

RAFT polymerization of $\mathrm{N}$-acryloylmorpholine (NAM) was performed using three dithioesters (DT) as chain transfer agents (CTA) incorporating in the R group a morpholine (Morpholine-DT), a biotin (Biotin-DT) and a sugar (Sugar-DT) moiety. PolyNAM chains of controlled characteristics were synthesized. An unexpected behavior was observed with Morpholine-DT, described as an "additional retardation" especially visible when low molar masses were targeted $\left(M_{\mathrm{n}}<5,000 \mathrm{~g} \cdot \mathrm{mol}^{-1}\right)$. In that particular case, further investigations using MALDI-ToF mass spectrometry showed the presence of terminated intermediate radicals (IR) corroborating the assumption based on a specific protection of IR according to the nature of the $\alpha$-chain-end.

\section{Introduction}

Reversible addition-fragmentation chain transfer (RAFT) polymerization ${ }^{[1]}$ is one of the controlled radical polymerization (CRP) processes developed in the last decade, together with nitroxide mediated polymerization $(\mathrm{NMP})^{[2]}$ and atom transfer radical polymerization $(\mathrm{ATRP})^{[3]}$. RAFT polymerization is carried out with chain transfer agents, typically thiocarbonylthio compounds which reversibly react with growing radicals via chain transfer reactions (Supporting information). Consequently, chains undergo successive active/dormant cycles that minimize termination reactions and lead to a simultaneous growth of all chains. The resulting polymer chains exhibit a narrow molar mass distribution and a controlled chain 
length. Moreover, complex architectures can be synthesized like block copolymers, graft copolymers and star copolymers. As RAFT polymerization applies to a wide variety of monomers and does not require rigorous experimental conditions, the potential macromolecular structures that can be prepared are extremely promising.

However, RAFT mechanism is not yet perfectly understood and one of the remaining questions relates to the so-called "retardation phenomenon". Indeed, for several monomer/CTA systems the polymerization rate is significantly slower than that of the corresponding conventional free radical polymerization (performed under identical conditions except for the presence of CTA). Typical systems exhibiting retarded kinetics are for instance: styrene or methyl acrylate/cumyl dithiobenzoate ${ }^{[4]}, \quad \mathrm{N}$-isopropylacrylamide/benzyl dithiobenzoate. ${ }^{[5]}$ In these cases, for a constant initiator concentration, the CTA concentration has a huge impact on the kinetics. The higher this concentration, the more retarded the polymerization. Such behavior is not general and some systems do not exhibit rate retardation while being under RAFT control. ${ }^{[6]}$ Most of the cases involving rate retardation correspond to dithiobenzoate mediated RAFT polymerizations.

With the aim to get $\alpha$-end-functionalized polymer chains, we have synthesized new RAFT agents bearing a molecule of interest in the $\mathrm{R}$ group ${ }^{[7]}$, such as a morpholine, a biotin, or a sugar. In this study, N-acryloylmorpholine (NAM) was chosen as monomer since the corresponding polymer is biocompatible, both water- and organo-soluble and since the RAFT polymerization of this monomer was already well studied by our group (Scheme 1). ${ }^{[8]}$ During the course of our kinetics investigations, an unexpected behavior was observed with one of the functional dithiobenzoates, described as an "additional retardation" especially visible when low molar masses were targeted $\left(M_{\mathrm{n}}<5,000\right.$ g.mol $\left.{ }^{-1}\right)$. In order to explain such a phenomenon, some hypotheses have been suggested and are presented in this communication 
together with experimental confirmations from kinetics and MALDI-TOF mass spectrometry results.

(a)

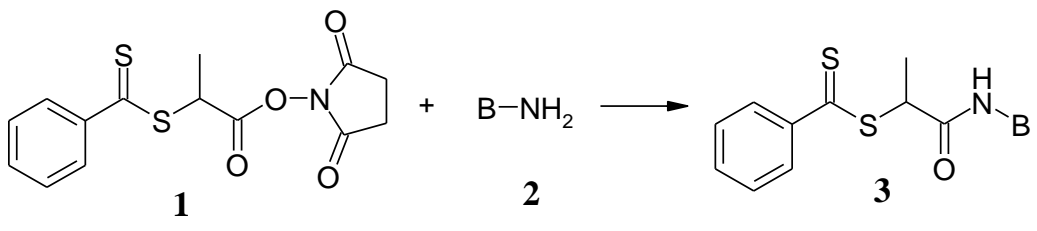

(b)<smiles>CC(SC(=S)c1ccccc1)C(=O)NCCN1CCOCC1</smiles>

3a

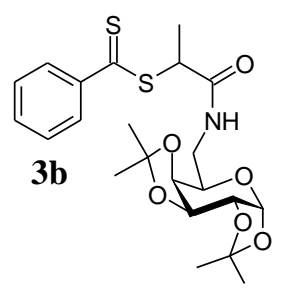<smiles>CC(SC(=O)c1ccccc1)C(=O)NCCOCCOCCNC(=O)CCCCC1SCC2NC(=O)NC21</smiles>

(c)<smiles></smiles>

Scheme 1: (a) Functional CTA synthesis from Precursor 1; (b) Structures of the synthesized functional CTA; (c) RAFT polymerization of $\mathrm{N}$-acryloylmorpholine (NAM).

\section{Experimental Part}

Materials. N-Acryloylmorpholine (NAM) (Aldrich, 97\%) was distilled under reduced pressure $\left(120^{\circ} \mathrm{C}, 10 \mathrm{mmHg}\right) .2,2^{\prime}$-Azobis(isobutyronitrile) (AIBN) (Fluka, 98\%) was purified by recrystallization from ethanol. 1,4-Dioxane (Acros, 99\%) was distilled over $\mathrm{LiAlH}_{4}(110$ ${ }^{\circ} \mathrm{C}$ ). Tetrahydrofuran (Aldrich, >99.5\%) was distilled over $\mathrm{Na}$ (in the presence of benzophenone). Trioxane (Acros, 99\%) and diethyl ether (SDS, 99.5\%) were used without further purification. RAFT agents $\mathbf{1}, \mathbf{3 a}, \mathbf{3 b}$ and $\mathbf{3 c}$ were synthesized according to a previously published procedure. ${ }^{[7]}$

Polymerization procedure. NAM (1.5 g, $10.6 \mathrm{mmol})$, CTA 3a (10.2 mg, $0.03 \mathrm{mmol})$, AIBN (0.49 mg, $0.003 \mathrm{mmol})$, dioxane $(5.31 \mathrm{~mL})$, and trioxane $\left(0.08 \mathrm{~g}\right.$, internal reference for ${ }^{1} \mathrm{H}$ NMR determination of monomer consumption) were introduced in a Schlenk tube equipped with a magnetic stirrer. The mixture was degassed by five freeze-evacuate-thaw cycles and 
then heated under nitrogen with a thermostated oil bath $\left(90^{\circ} \mathrm{C}\right)$. Periodically, samples were withdrawn from the polymerization medium for analyses.

Monomer conversion was determined by ${ }^{1} \mathrm{H}$ NMR spectroscopy using a Bruker AC 200 spectrometer (200 MHz), by comparison of one vinylic proton (5.7 ppm) with trioxane (5.1 ppm) ${ }^{[9]}$ Typically, $400 \mu \mathrm{L}$ of $d$-chloroform was added to $200 \mu \mathrm{L}$ of each sample. Polymers were precipitated in a large volume of diethyl ether, recovered by centrifugation, and finally dried under vacuum before analysis by size exclusion chromatography.

Characterization methods. Size exclusion chromatography (SEC) was performed using a Waters 510 pump and two Waters Ultrahydrogel columns (2000 and $500 \AA$ ). On-line double detection was provided by a differential refractometer (DRI Waters 410) and a three-angle $\left(47^{\circ}, 90^{\circ}, 130^{\circ}\right)$ MiniDAWN light scattering photometer (Wyatt Technologies), operating at $690 \mathrm{~nm}$. Analyses were performed by injection of $200 \mu \mathrm{L}$ of polymer solution $\left(5 \mathrm{mg} \cdot \mathrm{mL}^{-1}\right)$ in borate buffer $\left(\mathrm{pH}=9.3,0.05 \mathrm{~mol} . \mathrm{L}^{-1}\right)$, previously filtered $(0.22 \mu \mathrm{m}$ Millipore GS filter) and used as eluent at a flow rate of $0.5 \mathrm{~mL} \mathrm{~min}^{-1}\left(35^{\circ} \mathrm{C}\right)$. The specific refractive index increment $(\mathrm{dn} / \mathrm{dc})$ for poly(NAM) in the same eluent $(0.163)$ was previously determined with a NFT ScanRef monocolor interferometer operating at $633 \mathrm{~nm}$. The molar mass and polydispersity data were determined using the Wyatt ASTRA SEC/LS software package.

Matrix-assisted laser desorption ionization time-of-flight mass spectrometry (MALDI-ToF MS) measurements were performed with a Voyager-DE STR (Applied Biosystems, Foster City, CA). This instrument was equipped with a nitrogen laser (wavelength $337 \mathrm{~nm}$ ). The accelerating voltage was $20 \mathrm{kV}$. The positive ions were detected in all cases. The spectra were the sum of 200 shots, and an external mass calibration was used (mixture of peptides standards, Sequazyme kit). For an exact mass determination, an internal calibration based on the main peaks corresponding to dormant chains was performed. Samples were prepared by dissolving the polymer in freshly distilled tetrahydrofuran (THF) at a concentration of $10 \mathrm{~g} . \mathrm{L}^{-}$ 
1. The matrix was 1,8,9-trihydroxyanthracene (dithranol, Sigma-Aldrich), used without further purification and dissolved in distilled THF $\left(10\right.$ g. $\left.\mathrm{L}^{-1}\right)$. Matrix and polymer solutions were mixed at a volume ratio of 9:1 and $1 \mu \mathrm{L}$ of the resulting mixture was deposited onto a stainless steel target and dried before insertion into the ion source chamber.

\section{Results and Discussion}

With a view of producing bio-related $\alpha$-end functionalized polymer chains, a range of functional dithioesters were synthesized using a previously reported strategy (Scheme 1). ${ }^{[7]}$ Aminoethyl morpholine, a carbohydrate derivative (6-amino-6-desoxy-1,2:3,4-di-Oisopropylidene-6- $\alpha$-D-galactopyranose) and a biotin derivative ((+)-Biotinyl-3,6dioxaoctanediamine) were reacted with a precursor CTA $\mathbf{1}$ bearing an activated ester function. The resulting CTAs, 3a (Morpholine-DT), 3b (Sugar-DT) and 3c (Biotin-DT) were obtained with a high yield without any competitive degradation of the thiocarbonylthio moiety. ${ }^{[7]}$ In order to check if the presence of the biomolecule in the CTA structure would have any effect on the polymerization kinetics, several assays were carried out using $\mathrm{N}$-acryloylmorpholine (Scheme 1c) since RAFT polymerization of this monomer has been previously optimized. ${ }^{[8 c]}$ Polymerization of NAM in the presence of either $\mathbf{3 a}, \mathbf{3 b}$ or $\mathbf{3} \mathbf{c}$ was performed in dioxane at $90^{\circ} \mathrm{C}$ using $\mathrm{AIBN}$ as free radical source. The $[\mathrm{CTA}] /[\mathrm{AIBN}]$ molar ratio was chosen equal to 10 while average polymerization degrees of $355\left(M_{\mathrm{n}}=50,000\right.$ g.mol $\left.{ }^{-1}\right)$ and 28 $\left(M_{\mathrm{n}}=4,000 \mathrm{~g} \cdot \mathrm{mol}^{-1}\right)$ were targeted. In addition, a reference polymerization was conducted under the same conditions but without CTA (conventional free radical polymerization). Kinetics of the corresponding assays is presented in Figure 1. 

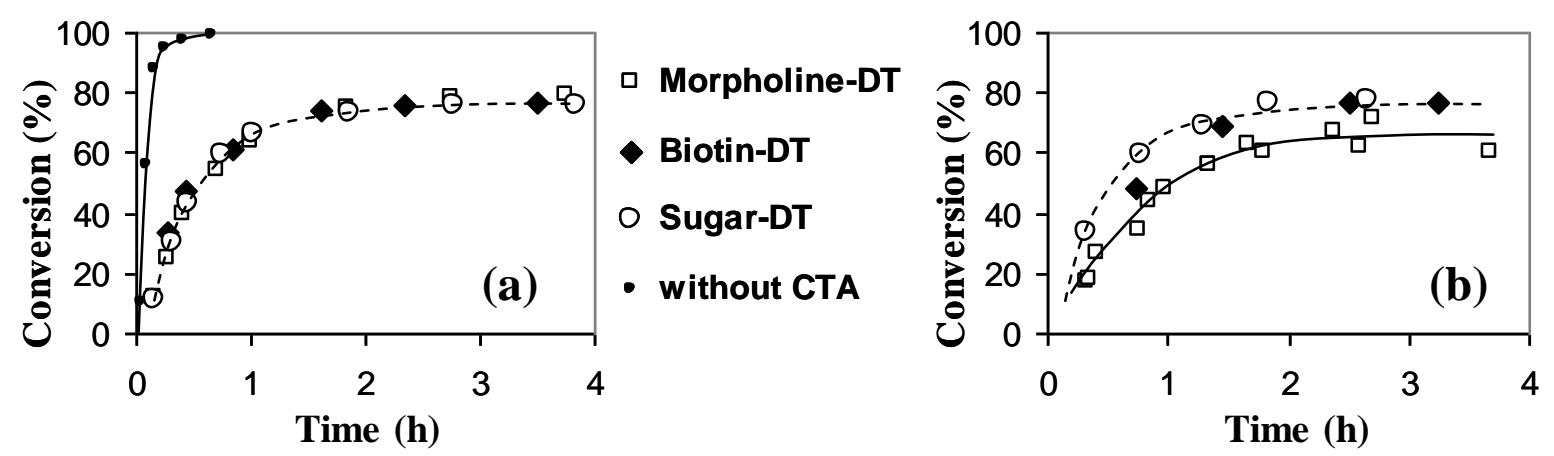

Figure 1: Kinetics of $N$-Acryloylmorpholine (NAM) polymerization mediated by various functional chain transfer agents in dioxane at $90{ }^{\circ} \mathrm{C} ;[\mathrm{NAM}]_{0}=1.6 \mathrm{~mol} . \mathrm{L}^{-1}$; $[\mathrm{CTA}]_{0} /[\mathrm{AIBN}]_{0}=10$. (a) $[\mathrm{NAM}]_{0} /[\mathrm{CTA}]_{0}=355$. (b) $[\mathrm{NAM}]_{0} /[\mathrm{CTA}]_{0}=28$.

Significant rate retardation is observed for all the RAFT polymerizations compared to the conventional one. However, the presence of various $\mathrm{R}$ groups in the dithioester does not seem to influence the kinetics when 50,000 g. mol ${ }^{-1}$ are targeted (Figure 1a). The linear evolution of molar masses versus conversion together with the low PDI values (see Supporting information) confirm the excellent control provided by these CTAs.

We have already observed for RAFT polymerization of several acrylamide derivatives mediated by tert-butyl dithiobenzoate, that a change in the targeted molar mass (i.e. $[\mathrm{NAM}] /[\mathrm{CTA}]$ ratio) does not affect the kinetics provided that the $[\mathrm{CTA}] /[\mathrm{AIBN}]$ ratio remained constant. ${ }^{[8 c]}+$ REF Bertrand For instance, when targeting lower molar masses, the enhanced retardation induced by the higher [CTA] is exactly balanced by the polymerization rate acceleration due to the higher $[\mathrm{AIBN}]$. It is indeed what is observed here when average polymerization degree is changed from 355 (Figure 1a) to 28 (Figure 1b), except for the RAFT polymerization mediated by Morpholine-DT where an additional retardation is noticed (experiment reproduced three times).

The origin of the rate retardation is indeed the subject of a scientific debate where two main explanations are put forward. One explanation assumes that intermediate radicals (IR) undergo slow fragmentation (inducing non negligible lifetimes). ${ }^{[4 \mathrm{~b}, 4 \mathrm{c}, 6,10]}$ The other is based on 
IR termination reactions thus reducing the total number of radicals in the polymerization medium. ${ }^{[1]}$ This second assumption would add another step to the accepted RAFT mechanism and such termination reactions would give rise to the formation of three arm star macromolecules. Under some specific conditions (in the presence of dormant chains but in absence of monomer), such species have been successfully detected, which demonstrates that their formation is sterically possible. ${ }^{[12]}$ However, such three arm star macromolecules have not been detected under RAFT polymerization conditions yet. A mix of these two hypothesis has rapidly been considered since they are not in opposition. ${ }^{[8]}$ The longer the lifetime of intermediate radicals, the higher the probability for termination. Another explanation suggested reversible termination reactions between two IR although the resulting species could not be detected. ${ }^{[13]}$ Recently, results from time-resolved ESR experiments led to the conclusion that slow fragmentation cannot be accepted without the occurrence of irreversible termination reactions onto IR. ${ }^{[14]}$

Applying the above mentioned assumptions for rate retardation to our results is not obvious. The ethyldithiobenzoate moiety being common to the three considered RAFT agents, it seems unlikely that fragmentation rate coefficient, $\mathrm{k}_{\mathrm{frag}}$, could be affected. Indeed, if the morpholine group had such an effect, polymerizations targeting higher molar masses $\left(50,000\right.$ g.mol $\left.{ }^{-1}\right)$ would also be kinetically affected. Concerning the assumption of irreversible termination reactions onto IR, it could be conceivable that IR would be more protected from side reactions for long polymer chain is conceivable (Scheme $2 b$ ). 


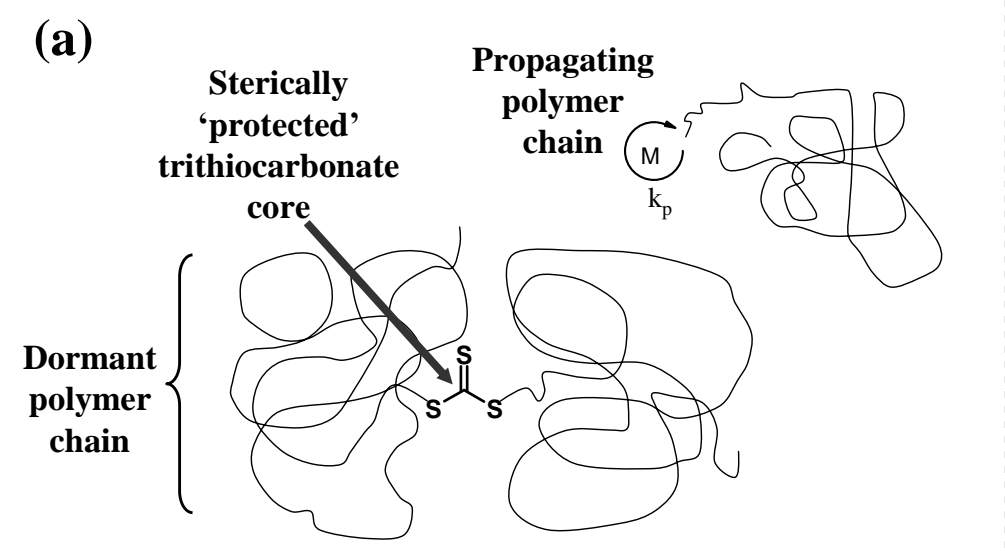

(b) High targeted $M_{n}$

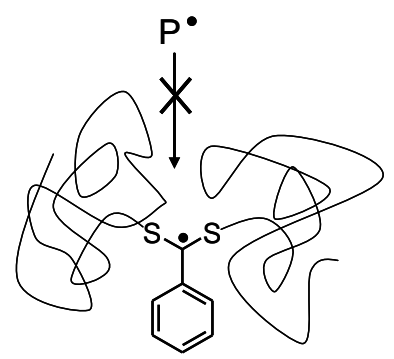

Sterically protected IR

(c)

Low targeted $M_{n}$ (two cases)

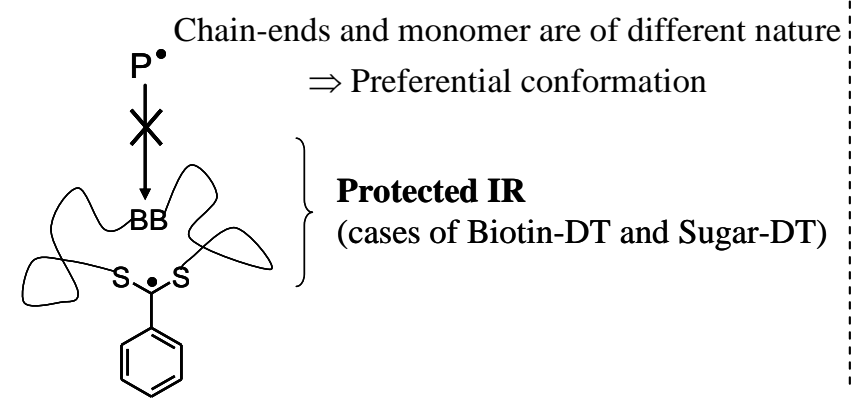

Chain-ends and monomer are of similar nature

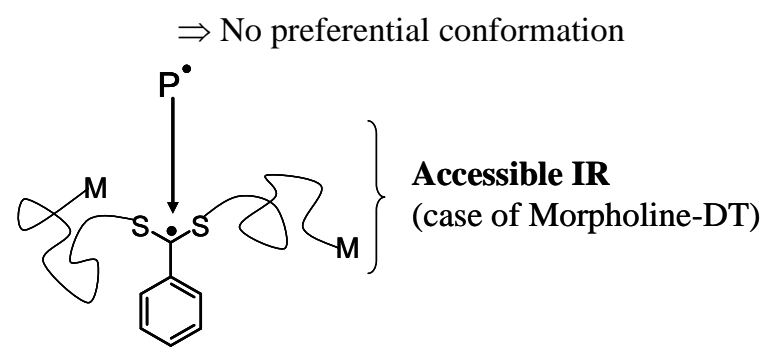

Scheme 2: (a) Proposed steric shielding for symmetrical trithiocarbonate mediated polymerization; ${ }^{[15]}$ (b) Sterically protected intermediate radical (IR) by long polymer chains; (c) Hypothesis to explain the over-retardation effect : probability of termination onto intermediate radicals depending on the nature of the chain-end.

A similar hypothesis has recently been proposed by Wang et al. (Scheme 2a) to explain the steric hindrance around a trithiocarbonate function when long polymer chains are targeted (molar masses higher than 30,000 g.mol ${ }^{-1}$ ) preventing an efficient reversible chain transfer. ${ }^{[15]}$ As a result, the control of the polymerization is lost whereas polymer chains of less than 7,000 g.mol ${ }^{-1}$ are perfectly controlled. Another example of steric shielding in RAFT polymerization was encountered in the case of Z-core type star architectures where steric crowding around the core prevented further chain extension. REF Martina 
In our case, an influence of the nature of the $\alpha$-chain-end is assumed, as depicted in Scheme 2c. Indeed, the morpholine group is chemically similar to the side chain of NAM monomer (Scheme 1c) and chains can freely move around the IR without any preferential conformation. Then, termination reactions onto IR may occur. According to this assumption, a ligand having a different nature than NAM monomer (such as a protected sugar or a biotin) could lead to a preferential conformation where the IR would be protected by a folding of the polymer chains. This would prevent the IR from termination reactions even for low molar masses.

One could assume that electronic effects are also involved as reported recently for stability studies of small radicals. 2 REF COOTE However, comparing the three dithiobenzoates used here, the structural similarity in the close environment of the dithioester function (up to the $\delta$ position) implies an electronic similarity. Then, electronic effects are probably not operating (ou bien: are probably not operating to a significant extent)."

In order to confirm the above assumption of specific shielding, an additional RAFT polymerization was carried out with a lower targeted molar mass $\left(2,000\right.$ g.mol ${ }^{-1}$, $[\mathrm{NAM}] /[\mathrm{CTA}]=14$ ) in the presence of either Sugar-DT (Figure 2a) or Morpholine-DT (Figure 2b).
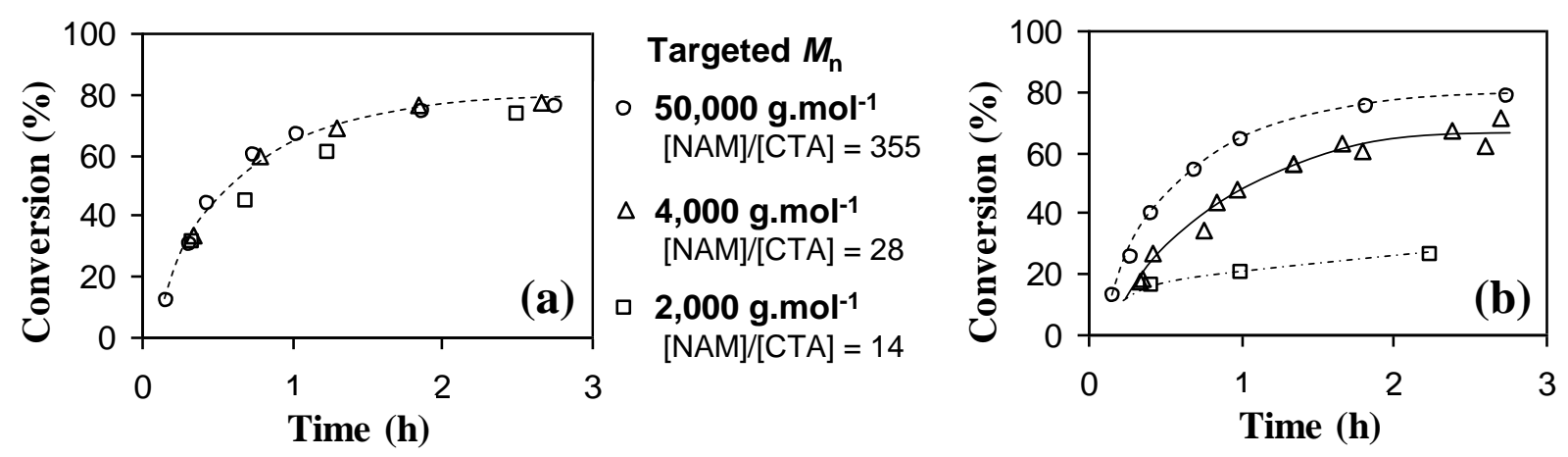

Figure 2: Kinetics of $N$-Acryloylmorpholine (NAM) polymerization mediated by SugarDT (a) and Morpholine-DT (b) in dioxane at $90{ }^{\circ} \mathrm{C} ;[\mathrm{NAM}]_{0}=1.6 \mathrm{~mol} . \mathrm{L}^{-1}$; $[\mathrm{CTA}]_{0} /[\mathrm{AIBN}]_{0}=10$. 
As shown in Figure 2, the over-retardation phenomenon is emphasized in the case of Morpholine-DT whereas very little effect can be observed in the polymerization mediated by Sugar-DT. This observation confirms the unique behavior of the morpholine based dithioester for NAM polymerization and is in agreement with a possible protection of IR with respect to the chain end for the two other dithioesters (case of low molar masses). Then, in the case of morpholine-DT, the probability of termination reactions onto IR should increase even more when low molar masses are targeted. Hence, the last sample (26\% conversion) was analyzed by MALDI-TOF mass spectrometry (Figure 3) in order to try and detect the possibly resulting three-arm star molecules.

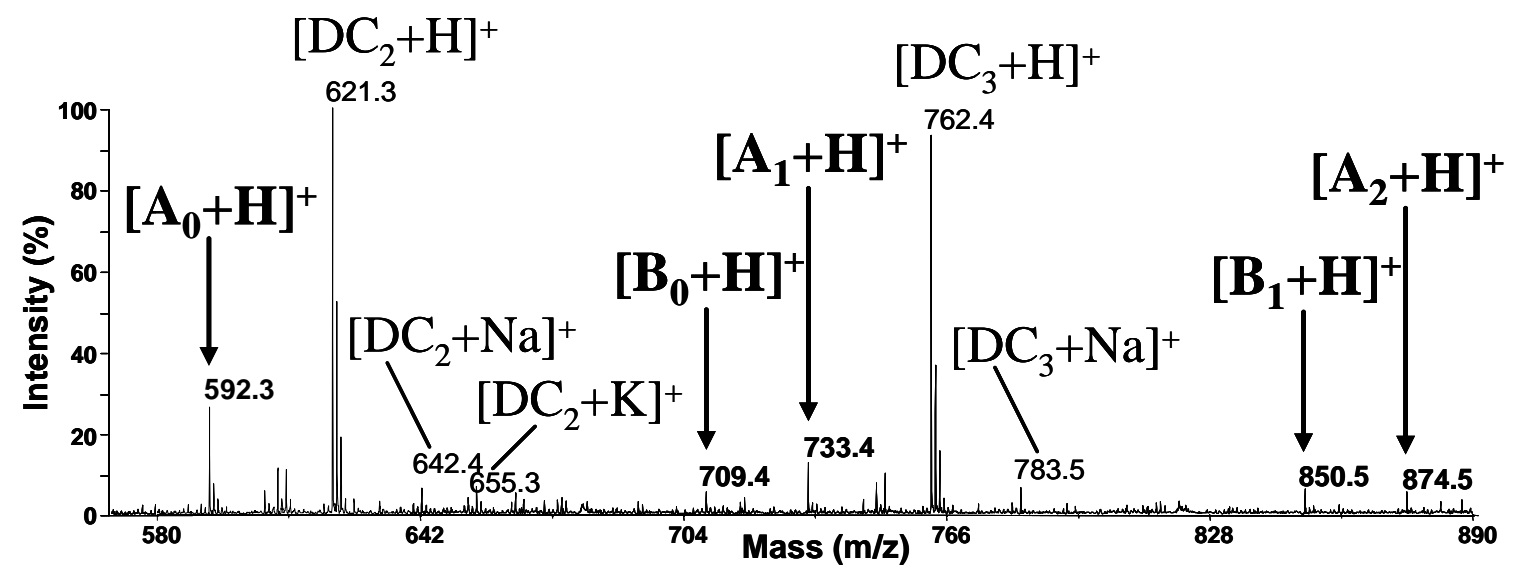

Figure 3: Positive ion MALDI-TOF mass spectrum in reflectron mode of Poly(NAM)Morpholine synthesized by RAFT polymerization of NAM in dioxane at $90{ }^{\circ} \mathrm{C}$; [NAM] $]_{0}$ $=1.6 \mathrm{~mol}^{-1} \mathrm{~L}^{-1} ;[\mathrm{CTA}]_{0} /[\mathrm{AIBN}]_{0}=10 ;[\mathrm{NAM}]_{0} /[\mathrm{CTA}]_{0}=14 ; 26 \%$ conversion. $\mathrm{DCx}$ : dormant chain of polymerization degree $X$. Structures of $A_{0}, A_{1}, A_{2}, B_{0}$ and $B_{1}$ : see Table 1 and Supporting information. * Structures not involving intermediate radicals; their assignments will be reported in a forthcoming paper.

The mass spectrum exhibits the expected populations (dormant chains) as already described for poly(NAM) synthesized by RAFT polymerization. ${ }^{[8 c, 16]}+$ Ref Bertrand nlle ref [10] In the case of Morpholine-functionalized poly(NAM) chains, an accurate analysis of the small peaks revealed the presence of populations $\left(\mathrm{A}_{0}, \mathrm{~A}_{1}, \mathrm{~A}_{2}, \mathrm{~B}_{0}, \mathrm{~B}_{1}\right)$ of molar masses consistent with terminated IR (Table 1). 
Table 1: Structures of detected terminated intermediate radicals.

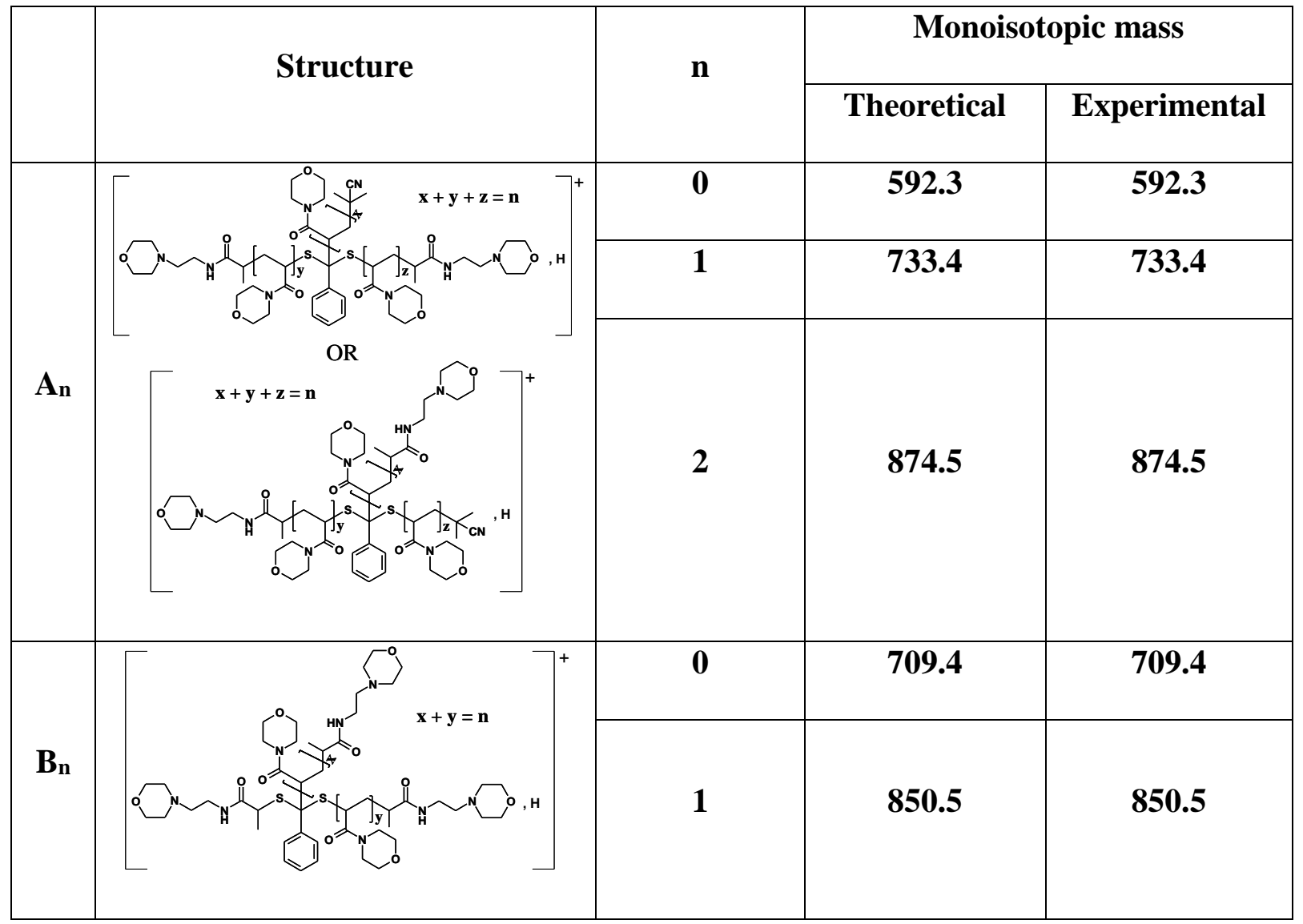

$\mathrm{A}_{0}$ corresponds to a terminated IR resulting from the addition of one fragment radical $\mathrm{R}^{\circ}$ (morpholino ethyl acrylamidyl) onto the initial CTA and terminated with a primary radical coming from the AIBN or vice versa. $\mathrm{B}_{0}$ corresponds to a terminated IR resulting from the addition of one fragment radical $\mathrm{R}^{\circ}$ onto the initial CTA and terminated with another $\mathrm{R}^{\circ} . \mathrm{A}_{1}$, $\mathrm{A}_{2}$ and $\mathrm{B}_{1}$ have the same structures but include one or two monomer units (that may be differently distributed). It is worth mentioning that in the case of the peaks where the signal/noise ratio was sufficient $\left(\mathrm{A}_{0}\right.$ and $\left.\mathrm{A}_{1}\right)$, an exact determination of mass unit was performed. The excellent agreement between theoretical ( $\mathrm{A}_{0}: 592.2986 \mathrm{mu}$ and $\mathrm{A}_{1}$ : 733.3775mu) and experimental values ( $\mathrm{A}_{0}: 592.3002 \mathrm{mu}$ and $\left.\mathrm{A}_{1}: 733.3761 \mathrm{mu}\right)$ provides a very strong evidence of the given structures. 
These structures were not observed for a sample of polyNAM chains obtained in the presence of sugar-DT, which confirms that the nature of the chain-end can affect the probability of termination onto oligomeric IR. These results are the first observation of terminated IR in a sample arising from a RAFT polymerization. Moreover, they provide an experimental confirmation that primary radicals (and not only oligoradicals) are involved in the preequilibrium (addition onto a CTA). Finally, these results suggest that the assumption of irreversible termination reactions onto IR is not sufficient to explain the so-called retardation phenomenon.

\section{Conclusion}

Termination onto intermediate radicals is probably the origin of the over-retardation phenomenon observed when RAFT polymerization of NAM is mediated by Morpholin-DT for targeted molar masses lower than 5,000 g. $\mathrm{mol}^{-1}$. For higher molar masses, whatever the nature of the chain-end, the steric hindrance around the IR seems efficient enough to prevent termination. When low molar masses are targeted, in the unique case of Morpholin-DT, the similar chemical nature of the chain-end and of the monomer unit may avoid such a folding of the polymer chains around the IR center which is thus not protected towards termination. Such terminated IR have been experimentally observed by MALDI TOF mass spectrometry for the first time under RAFT polymerization conditions. Their structure corresponds to very low polymerization degrees. On the contrary, RAFT polymerizations mediated by sugar-DT and biotin-DT are retarded without being over-retarded. Our results suggest that the assumption of irreversible termination reactions onto IR is not sufficient to explain the main retardation phenomenon observed in RAFT polymerization mediated by dithiobenzoates and may help to the general understanding of RAFT mechanism. 


\section{Acknowledgments}

The authors would like to thank F. Delolme (SCA, Vernaison, France) for the MALDI-ToF MS analyses.

\section{Supporting Information}

Supporting Information Available: RAFT general mechanism, Evolution of molar masses and polydispersity indexes (PDI) versus conversion for $N$-Acryloylmorpholine (NAM) polymerization mediated by various functionalized chain transfer agents (CTA) in dioxane at $90^{\circ}$, possible structure for detected terminated intermediate radicals $A_{0-2}, B_{0-1}$. 


\section{References}

[1] [1a] G. Moad, E. Rizzardo, S.H. Thang, Aust. J. Chem. 2005, 58, 349; [1b] S. Perrier, P. Takolpuckdee, J. Polym. Sci. Part A: Polym. Chem. 2005, 43, 5347; [1c] A. Favier, M-T. Charreyre, Macromol. Rapid Commun. 2006, 27, 653.

[2] C.J. Hawker, A.W. Bosman, E. Harth, Chem. Rev. 2001, 101, 3661.

[3] [3a] K. Matyjaszewski, J. Xia, Chem. Rev. 2001, 101, 2921; [3b] M. Kamigaito, T. Ando, M. Sawamoto, Chem. Rev. 2001, 101, 3689.

[4] [4a] G. Moad, J. Chiefari, Y.K. Chong, J. Krstina, R.T.A. Mayadunne, A. Postma, E. Rizzardo, S.H. Thang, Polym. Int. 2000, 49, 993; [4b] C. Barner-Kowollik, J.F. Quinn, D.R. Morsley, T.P. Davis, J. Polym. Sci. Part A: Polym. Chem. 2001, 39, 1353; [4c] S. Perrier, C. Barner-Kowollik, J.F. Quinn, P. Vana, T.P. Davis, Macromolecules 2002, 35, 8300.

[5] F. Ganachaud, M.J. Monteiro, R.G. Gilbert, M-A. Dourges, S.H. Thang, E. Rizzardo, Macromolecules 2000, 33, 6738.

[6] C. Barner-Kowollik, J.F. Quinn, T.L.U. Nguyen, J.P.A. Heuts, T.P. Davis, Macromolecules 2001, 34, 7849.

[7] M. Bathfield, F. D'Agosto, R. Spitz, M-T. Charreyre, T. Delair, J. Am. Chem. Soc. 2006, $128,2546$.

[8] [8a] A. Favier, M-T. Charreyre, P. Chaumont, C. Pichot, Macromolecules 2002, 35, 8271; [8b] F. D’Agosto, R. Hughes, M.T. Charreyre, C. Pichot, R.G. Gilbert, Macromolecules 2003, 36, 621. [8c] A. Favier, M-T. Charreyre, C. Pichot, Polymer 2004, 45, 8661.

[9] F. D'Agosto, M-T. Charreyre, L. Veron, M-F. Llauro, C. Pichot, Macromol. Chem. Phys. 2001, 202, 1689.

REF Bertrand: De Lambert B, Charreyre MT, Chaix C, Pichot C. Polymer 2005;46:623.

[10] C. Barner-Kowollik, M.L. Coote, T.P. Davis, L. Radom, P. Vana, J. Polym. Sci., Part A: Polym. Chem. 2003, 41, 2828.

[11] [11a] H. de Brouwer, M.A.J. Schellekens, B. Klumperman, M.J. Monteiro, A.L. German, J. Polym. Sci., Part A: Polym.Chem. 2000, 38, 3596; [11b] M.J. Monteiro, H. de Brouwer, Macromolecules 2001, 34, 349; [11c] Y. Kwak, A. Goto, Y. Tsujii, Y. Murata, K. Komatsu, T. Fukuda, Macromolecules 2002, 35, 3026; [11d] A.R. Wang, S. Zhu, Y. Kwak, A. Goto, T. Fukuda, M.J. Monteiro, J. Polym. Sci., Part A: Polym. Chem. 2003, 41, 2833.

[12] [12a] Y. Kwak, A. Goto, T. Fukuda, Macromolecules 2004, 37, 1219; [12b] Y. Kwak, A. Goto, K. Komatsu, Y. Sugiura, T. Fukuda, Macromolecules 2004, 37, 4434; [12c] R. Venkatesh, B.B.P. Staal, B. Klumperman, M.J. Monteiro, Macromolecules 2004, 37, 7906.

[13] C. Barner-Kowollik, P. Vana, J.F. Quinn, T.P. Davis, J. Polym. Sci. Part A: Polym. Chem. 2002, 40, 1058.

[14] M. Buback, P. Hesse, T. Junkers, P. Vana, Macromol. Rapid Commun. 2006, 27, 182.

[15] R. Wang, C.L. McCormick, A.B. Lowe, Macromolecules 2005, 38, 9518.

REF Martina stars: M. Stenzel-Rosenbaum, T. P. Davis, V. Chen, A. G. Fane, J. Polym. Sci., Part A: Polym. Chem. 2001, 39, 2777. 
Note: As suggested by one of the reviewer, according to such a steric shielding effect, the termination rate coefficients of intermediate radicals could be much lower than those of propagating radicals in a conventional free radical polymerization.

2 REF COOTE : Coote, M.L.; Krenske, E. H.; Izgorodina, E. I. Macromol. Rapid Commun. 2006, 27, 473

Coote, M.L.; Krenske, E. H.; Izgorodina, E. I.; Busch, M.; Barner-Kowollik, C. Macromol. Rapid Commun. 2006, 27, 1015.

[16] A. Favier, C. Ladavière, M-T. Charreyre, C. Pichot, Macromolecules 2004, 37, 2026. 


\section{Captions to Figures}

Figure 1: Kinetics of $\mathrm{N}$-Acryloylmorpholine (NAM) polymerization mediated by various functional chain transfer agents in dioxane at $90{ }^{\circ} \mathrm{C} ;[\mathrm{NAM}]_{0}=1.6 \mathrm{~mol} . \mathrm{L}^{-1} ;[\mathrm{CTA}]_{0} /[\mathrm{AIBN}]_{0}$ $=10$. (a) $[\mathrm{NAM}]_{0} /[\mathrm{CTA}]_{0}=355$. (b) $[\mathrm{NAM}]_{0} /[\mathrm{CTA}]_{0}=28$.

Figure 2: Kinetics of $\mathrm{N}$-Acryloylmorpholine (NAM) polymerization mediated by Sugar-DT (a) and Morpholine-DT (b) in dioxane at $90{ }^{\circ} \mathrm{C} ;[\mathrm{NAM}]_{0}=1.6 \mathrm{~mol} \cdot \mathrm{L}^{-1} ;[\mathrm{CTA}]_{0} /[\mathrm{AIBN}]_{0}=$ 10.

Figure 3: Positive ion MALDI-TOF mass spectrum in reflectron mode of Poly(NAM)Morpholine synthesized by RAFT polymerization of $\mathrm{NAM}$ in dioxane at $90{ }^{\circ} \mathrm{C}$; [NAM] 0 $=1.6 \mathrm{~mol} . \mathrm{L}^{-1} ;[\mathrm{CTA}]_{0} /[\mathrm{AIBN}]_{0}=10 ;[\mathrm{NAM}]_{0} /[\mathrm{CTA}]_{0}=14 ; 26 \%$ conversion. $\mathrm{DCX}_{\mathrm{X}}$ : dormant chain of polymerization degree $X$. Structures of $A_{0}, A_{1}, A_{2}, B_{0}$ and $B_{1}$ : see Table 1. * Structures not involving intermediate radicals; their assignments will be reported in a forthcoming paper. 


\section{Additional Retardation in RAFT Polymerization:}

\section{Detection of Terminated Intermediate Radicals}

Maël Bathfield, ${ }^{1,2}$ Franck D'Agosto, ${ }^{* 1}$ Roger Spitz, ${ }^{1}$ Catherine Ladavière, ${ }^{2}$ Marie-Thérèse Charreyre, ${ }^{* 2}$ Thierry Delair ${ }^{2}$

\section{Supporting Information}

1. Laboratoire de Chimie et Procédés de Polymérisation UMR 140 CNRS/ESCPE, Bât 308 F, 43 Boulevard du 11 Novembre 1918, BP 2077, 69616 Villeurbanne CEDEX, France

2. Unité Mixte CNRS/bioMérieux, École Normale Supérieure de Lyon, 46 allée d'Italie, 69364 Lyon Cedex 07, France

Corresponding Authors: F. D’Agosto (ㅁgosto@lcpp.cpe.fr), M.T. Charreyre (mtcharre@enslyon.fr)

Supporting Information Available: RAFT general mechanism, Evolution of molar masses and polydispersity indexes (PDI) versus conversion for $N$-Acryloylmorpholine (NAM) polymerization mediated by various functionalized chain transfer agents (CTA) in dioxane at $90{ }^{\circ} \mathrm{C}$, Possible structure for detected terminated intermediate radicals $\mathrm{A}_{0-2}, \mathrm{~B}_{0-1}$. 
$\mathrm{I}_{2} \underset{k_{d}}{\stackrel{\text { Initiation }}{\longrightarrow}} 2 \mathrm{\ominus}^{\stackrel{\mathrm{M}}{\longrightarrow}} \mathrm{Pn}^{\bullet}$

Chain transfer (pre-equilibrium)

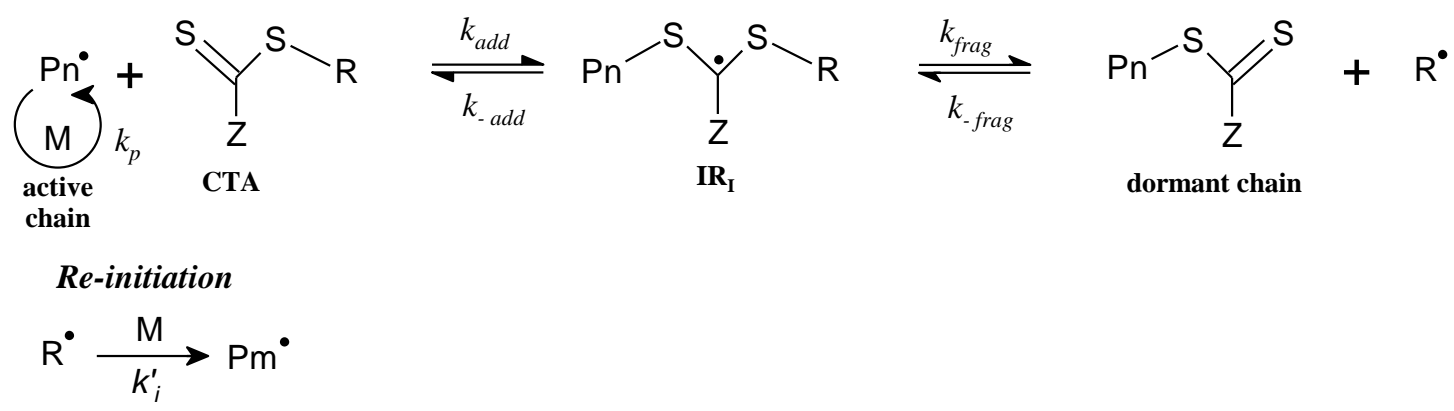

Equilibrium between active and dormant chains

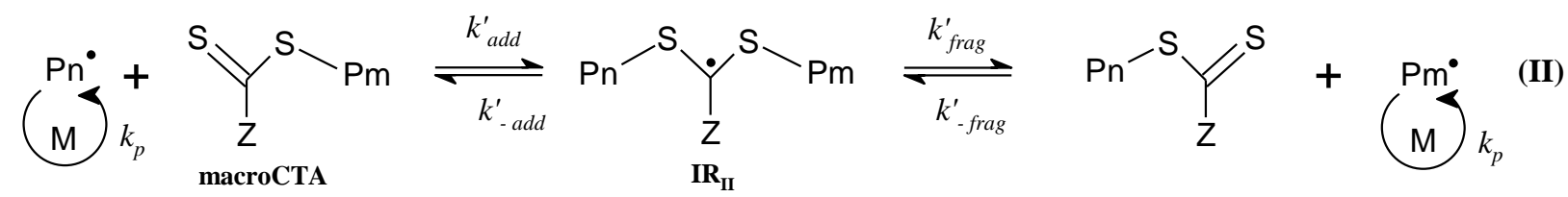

\section{Termination}

$\mathrm{Pn}^{\bullet}+\mathrm{Pm}^{\bullet} \underset{k_{t}}{\longrightarrow}$ dead chains

Scheme 1: General mechanism of the RAFT polymerization. 


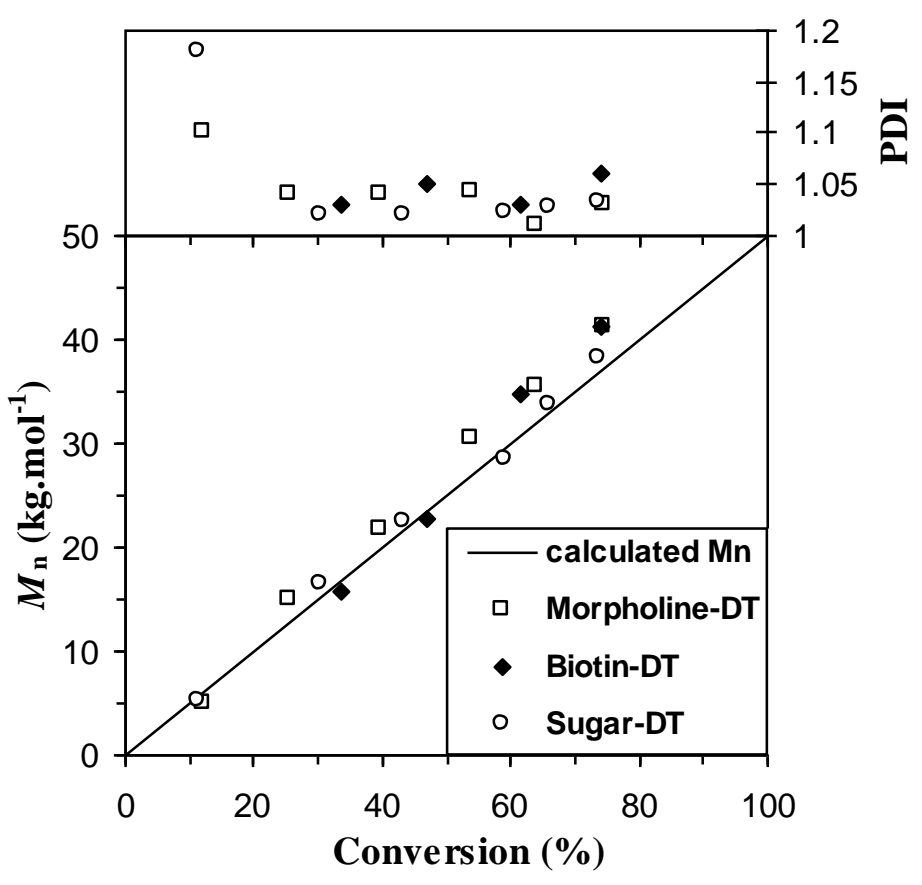

Figure 1: Evolution of molar masses and polydispersity indexes (PDI) versus conversion for $N$-Acryloylmorpholine (NAM) polymerization mediated by various functionalized chain transfer agents (CTA) in dioxane at $90{ }^{\circ} \mathrm{C} ;[\mathrm{NAM}]_{0}=1.6 \mathrm{~mol}^{\circ} \mathrm{L}^{-1}$; [CTA $]_{0} /[\mathrm{AIBN}]_{0}$

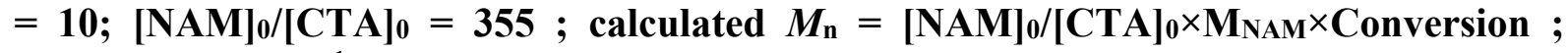
$\left(\mathrm{M}_{\mathrm{NAM}}=141 \mathrm{~g} \cdot \mathrm{mol}^{-1}\right)$. 


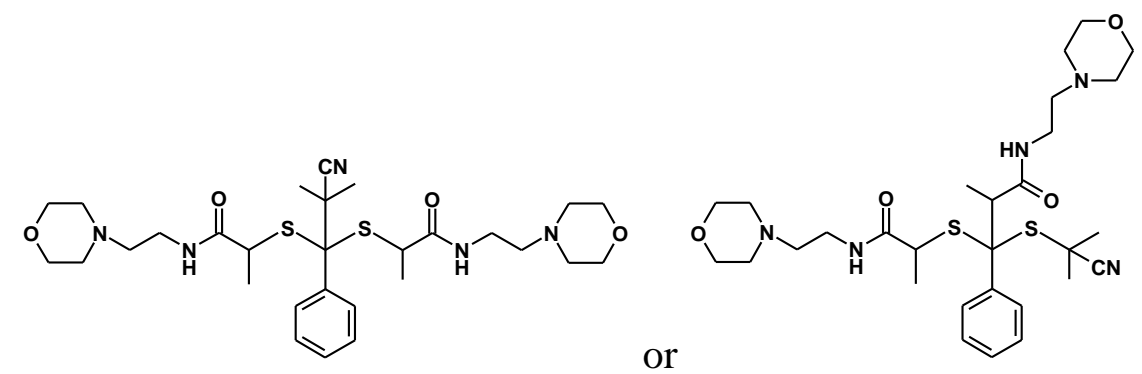

$\mathbf{A}_{1}$

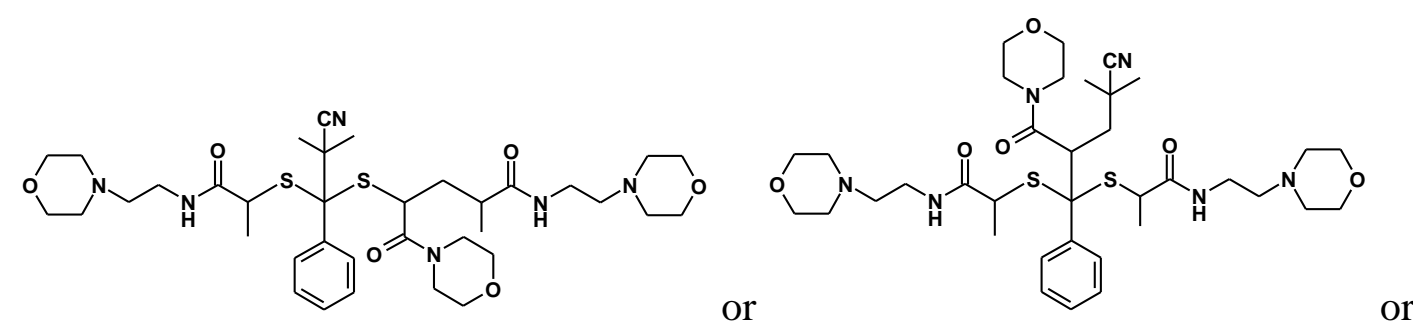<smiles>CC(SC(C)(C(C)C(=O)NCCN1CCOCC1)C(SC(CC(C)(C)C)C(=O)N1CCOCC1)c1ccccc1)C(=O)NCCN1CCOCC1</smiles>

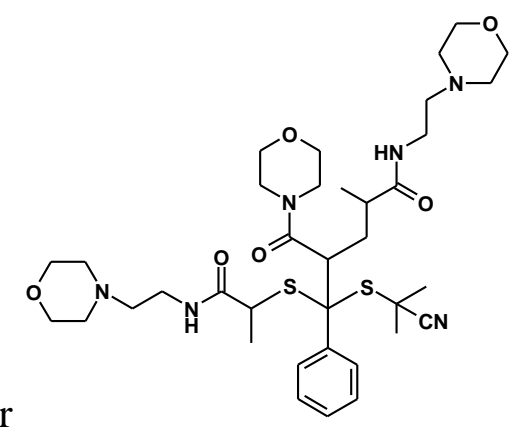

Scheme 2: Possible structures of detected terminated intermediate radicals $A_{0}$ and $A_{1}$. 
$\mathbf{A}_{2}$<smiles>CC(CC(SC(SC(CC(C(=O)NCCN1CCOCC1)C(=O)NCCN1CCOCC1)C(=O)N1CCOCC1)(c1ccccc1)C(C)(C)C)C(=O)N1CCOCC1)C(=O)N1CCOCC1</smiles><smiles>CC(CC(SC(SC(C)C(=O)N1CCOCC1)(c1ccccc1)C1C(=O)C2COCCN2C1=O)C1COCCC(C)(C)C1)C(=O)NCCN1CCOCC1</smiles>

or<smiles>CC(CC(SC(SC(CC(C)(C)N)C(=O)N1CCOCC1)(c1ccccc1)C(C)C(=O)NCCN1CCOCC1)C(=O)N1CCOCC1)C(=O)NCCN1CCOCC1</smiles><smiles>CC(CC(SC(CC(C)C(=O)NCCN1CCOCC1)(SC(C)(C)N)C(=O)N1CCOCC1)C(=O)N1CCOCC1)C(=O)NCCN1CCOCC1</smiles>

or<smiles>CC(CC(C(=O)N1CCOCC1)C(SC(C)C(=O)NCCN1CCOCC1)(SC(CC(C)C(=O)N1CCOCC1)C(=O)N1CCOCC1)c1ccccc1)C(=O)NCCN1CCOCC1</smiles><smiles>CC(CC(CC(SC(SC(C)C(=O)NCCN1CCOCC1)(c1ccccc1)C(C)(C)C)C(=O)N1CCOCC1)C(=O)N1CCOCC1)C(=O)NCCN1CCOCC1</smiles><smiles>CC(SC(SC(CC(CC(C)(C)C)C(=O)N1CCOCC1)C(=O)N1CCOCC1)(c1ccccc1)C(C)C(=O)NCCN1CCOCC1)C(=O)NCCN1CCOCC1</smiles><smiles>CC(SC(SC(C)C(=O)NCCN1CCOCC1)(c1ccccc1)C(CC(CC(C)(C)N)C(=O)N1CCOCC1)C(=O)N1CCOCC1)C(=O)NCCN1CCOCC1</smiles>

or<smiles>CC(CC(CC(SC(SC(C)(C)N)(c1ccccc1)C(C)C(=O)NCCN1CCOCC1)C(=O)N1CCOCC1)C(=O)N1CCOCC1)C(=O)NCCN1CCOCC1</smiles>

Scheme 3: Possible structures of detected terminated intermediate radicals A2. 
<smiles>CC(SC(SC(C)C(=O)NCCN1CCOCC1)(c1ccccc1)C(C)C(=O)NCCN1CCOCC1)C(=O)NCCN1CCOCC1</smiles>

$\mathbf{B}_{1}$<smiles>CC(CC(SC(SC(C)C(=O)NCCN1CCOCC1)(c1ccccc1)C(C)C(=O)NCCN1CCOCC1)C(=O)N1CCOCC1)C(=O)NCCN1CCOCC1</smiles><smiles>CC(CC(C(=O)N1CCOCC1)C(SC(C)C(=O)NCCN1CCOCC1)(c1ccccc1)C(C)C(=O)NCCN1CCOCC1)C(=O)NCCN1CCOCC1</smiles>

Scheme 4: Possible structures of detected terminated intermediate radicals $B_{0}$ and $B_{1}$. 